\title{
STUDENTS' PERCEPTION ON TEACHER-STUDENTS' INTERACTION IN AN ONLINE LEARNING ENVIRONMENT
}

\author{
${ }^{1}$ Ruth Eliana Franssisca \& ${ }^{1,2}$ Fransisca Endang Lestariningsih \\ ${ }^{1}$ Duta Wacana Christian University, Indonesia \\ ${ }^{2}$ Corresponding Author Email: endang@ staff.ukdw.ac.id
}

\begin{tabular}{|c|c|}
\hline Article Info & Abstract \\
\hline History & \multirow{2}{*}{$\begin{array}{l}\text { Online learning environment is one of the ways to conduct a learning activity. It } \\
\text { usually uses some internet-based programs to support the learning activity } \\
\text { including teacher-students' interaction. Many challenges are considered to occur } \\
\text { more on online learning rather than on site learning. Due to its limitation, online } \\
\text { learning environment is questioned to be an effective way in providing interaction } \\
\text { among teacher and students. Thus, this paper aims to find students' perspective of } \\
\text { teacher-students interaction in an online learning environment. Moreover, to } \\
\text { collect the data from the participants, this study used an interview to get in-depth } \\
\text { information to see students' perspective on the related topic. The result shows that } \\
\text { two-ways discussion was preferably chosen by the participants and feedback } \\
\text { should be given orally, rather than in written form, to help the participants } \\
\text { understand more about the materials. }\end{array}$} \\
\hline $\begin{array}{l}\text { Key } \\
\text { Onli } \\
\text { Stud } \\
\text { Teac } \\
\text { inter }\end{array}$ & \\
\hline
\end{tabular}

How to cite: Fransisca, R. E., \& Lestariningsih, F. E. (2021). Students' perception on teacher-students' interaction in an online learning environment, JOLLT Journal of Languages and Language Teaching, 9(3) DOI: https://doi.org/10.33394/jollt.v\%vi\%i.3782

\section{INTRODUCTION}

Due to the Covid-19 pandemic situation that first struck Indonesia in 2020, almost all academic institutions have declared a policy to get their students to have distance learning or online-based learning. Even though distance learning has been widely known, the sudden use of this instructional methods was challenging for both teachers and students. The understandings and how to effectively use it has not yet been familiar to both parties.

Distance learning is for wide range purposes (Bušelić, 2012). Moreover, it uses technological-based programs to support the learning that is held over distance (Malinovski, Lazarova, \& Trajkovik, 2012). Similarly to distance learning, Bakia, Shear, Toyama, and Lasseter (2012) state that online learning is the term that is usually used for referring to a wide range of some internet-based programs to provide an instructional material and facilitate teacher-students and students-students interaction. The students-students' interaction is an activity of online learning that is assumed to make learners to have autonomy in learning. Autonomy means being independent in which the students are independent in their learning such as setting the learning goals, finding the learning materials by themselves and monitoring their progress in learning (Najeeb, 2013). The independent learners also want to act independently to have co-operation with other students or teacher in order to achieve the successful learning, it means the learners are socially responsible (Little, 1995). Moreover, the teacher-students interaction includes giving feedback verbally and non-verbally through in distance (Terzi \& Çelik, 2005). The feedback enables students to meet their needs to fulfil the academic outcomes (Arkorful \& Abaidoo, 2015). Moreover, for teachers, it enables teacher to use verbal and verbal and non-verbal signs to adjust the instruction in real time, particularly in conventional classroom (Terzi \& Çelik, 2005). However, in distance learning environment, teachers are hardly having an access to verbal and non-verbal feedbacks from the students 
(Terzi \& Çelik, 2005). This may create a gap between teacher-students' interaction to successful learning.

Due to the above rationale, this article is to answer the question of what the students' perspective of teacher-students' interaction in online learning environment is?

\section{Advantages and Disadvantages of Online Learning}

In this globalization era, internet has becoming one of crucial ways to create an available resource for research and learning for teachers and students to share the acquired information (Hartshorne \& Ajjan, 2009). The use of technology in learning is also becoming one of the requirements in this $21^{\text {st }}$ century era (Lara, 2006). Therefore, learning nowadays is not merely conducted in a conventional classroom, yet also through some online devices and programs and it is called online learning. This kind of process of learning may bring some benefits or drawbacks (Arkorful \& Abaidoo, 2015). The benefits are; teachers and students can communicate frequently compared to face-to-face meeting (Terzi \& Çelik, 2005) . It can be done at the day and night. For instance, when the questions arise during anytime, students can simply ask the teacher. Further, the students tend to have less embarrassment in asking questions to the teacher in online learning environment compared to conventional type of learning (Rahmawati, 2016). Besides that, the students can be more active in managing their learning. For instance, in higher education, online learning empowers students acquiring their education as well as perusing their own objectives and maintaining the careers of theirs (Arkorful \& Abaidoo, 2015). This situation helps students to be more independent in learning to achieve the academic outcomes. Moreover, online learning more focuses on the needs of the individual learners as the important aspect in education rather than on the institutions or teachers' needs (Arkorful \& Abaidoo, 2015). In contrast, online learning also has some drawbacks. Some studies have found the major drawback of online learning. As according to $\mathrm{Ku}$ and Lohr (2000), the major drawback is related to the technical problems in which the students usually have problems in accessing the online programs. Furthermore, online learning is inconsistent in terms of the use of online learning in different courses, the dependency on electronic devices, and lack of individuals contact (Keller \& Cernerud, 2002).

\section{The Students' Perspectives on Teacher-Students' Interaction in Online Learning}

There are many studies were conducted to see students perception on teacher-students interaction in online learning environment (e.g,. Coldwell-Neilson, Craig, \& Goold, 2006; Lam, Lee, Chan, \& McNaught, 2011; Lefoe, Gunn, \& Hedberg, 2002; Singh, Donoghue, \& Worton, 2002). For instance, Lefoe et al. (2002) found that teacher and students' interaction was not good in online learning environment due to the limit access of communication. Moreover, the debate and study about students' perspective on online learning is seemed to be sparse (Keller \& Cernerud, 2002). However, Lam et al. (2011) found that students were finding online learning as the way that provided an effective interaction between students to students and teacher to students. The students felt there was no obstacle to make a discussion with the teacher. Further, as according to Keller \& Cernerud (2002), online learning also provides an opportunity to the students to reflect and think about their ideas. Thus, online learning may help students to be more independent (Bakia et al., 2012). In contrast, feedbacks are not always possible to be given in online learning environment (Lefoe et al., 2002). Moreover, based on few studies, students view teachers having a significant and crucial role in online learning rather than merely technologies (Keller \& Cernerud, 2002; Rahmawati, 2016) since the teachers should provide continuous instruction and supervision to the students (Rahmawati, 2016). 


\section{RESEARCH METHOD}

\section{Research Design}

This study is conducted using interpretivist paradigm and qualitative method to gather data from participants. The qualitative method aims to find in-depth information from the participant and it can help researchers to explore a wide range of 'dimension of social world' including participants' experiences, understanding, everyday life situation, and their process of social life (Mason, 2002), for example, related to their educational environment. Interpretivist paradigm itself is a paradigm in which the researcher sees data from the people's perspective, interpretations, meanings and understanding (Mason, 2002).

\section{Research Instrument and Participants}

For collecting the qualitative data, this study used interview. The interview is conducted to collect data from three university students who are pursuing their bachelor degrees in some private universities in Indonesia. Since this study aims to find students' views on the teacher-students' interaction, the interview consists of several guideline questions related to the interaction between teachers and students during the distance online learning. To avoid bias, the interview was done in Bahasa Indonesia.

\section{Data analysis}

The result of the interview was transcribed and then translated into English. As according to Kielmann, Cataldo, and Seeley (2012), transcribing the result of qualitative data is important since the researchers can familiarise themselves with the data and the context on which the data are collected. Moreover, translating the collected data is also important since it helps researchers to signify themes and sub-themes (Kielmann et al., 2012). These themes and sub-themes are important to develop the analysis (Mason, 2002) and it can be processed after doing a coding and thematic analysis. Coding was done for the need of finding the relevance in the qualitative data to the research question (Elliott, 2018). Lastly, thematic analysis aims to elucidate theme (Vaismoradi et al., 2016).

\section{Ethical Considerations}

In conducting a research, it is important for researchers to apply principles of ethics (Fleming \& Zegwaard, 2018). Hence, this study applies three research ethics principles; autonomy, anonymity, and beneficence. The participants' consents were asked orally. Thus, the involvement of the participants will be voluntarily. It supports autonomy as one of principles in research ethics in which the participants can decide their participation in the study themselves (Vilma, 2018). That is important since it means researchers do not give any pressure to any participants to agree for participating in their study (Silverman, 2011). In informed consent form, the description of the study then should be stated, thus the participants know what kind of study is conducted (Creswell, 2014). The second ethics principle that is applied is anonymity in which the researcher does not publish participants' names, information, and self-identifying statements to keep them confidential and anonymous (Fleming \& Zegwaard, 2018). The last ethics principle that is applied is beneficence where the researcher highlights the benefits of the study (Fleming \& Zegwaard, 2018). Thus, this study tries to maximize the benefits for the participants.

\section{RESEARCH FINDINGS AND DISCUSSION}

The interview to three participants results in the awareness among them that online learning is the best choice in this situation instead of conventional learning. When they were asked about how effective it was using online platform in communicating between teachers and students, they mostly revealed that it helped them to have better communication, as can 
be seen in Table 1. However, one participant revealed that having conventional meeting (faceto-face) was better since he could have more insight and ideas.

Table 1

Students' Perception on Communication Using Online Platform

\begin{tabular}{lcl}
\hline No & Student & \multicolumn{1}{c}{ Response } \\
\hline 1 & A & $\begin{array}{l}\text { "Using online platform helps me to have communication with my teacher, but I } \\
\text { personally do not think that it is effective compared to face to face classroom since } \\
\text { online platform has its limitation as well" } \\
\text { "To me, I do not think it helps me effectively in having communication with my } \\
\text { teacher, particularly when I have to consult my paper. In conventional learning, I can } \\
\text { have more insight and ideas compared to through online discussion." } \\
\text { Online learning is still effective to have communication with teacher as long as it is } \\
\text { an audio or voice or teleconference meeting }\end{array}$ \\
\hline
\end{tabular}

The fact showing that students felt at ease communicating with the teacher was in line with what Lam et al. (2011) argued that students were finding online learning as the way providing an effective interaction between students and teacher to students. The students felt there was no difficulty to make a discussion with the teacher. In contrast, one participant who found that in direct face-to-face interaction he could have more ideas was also in line with the findings shown by Lefoe et al who argued that feedbacks are not always possible to be given in online learning environment (2002).

Table 2

Students' Perspective on How to Make Online Learning Effective

\begin{tabular}{lcl}
\hline No & Students & \multicolumn{1}{c}{ Response } \\
\hline 1 & A & $\begin{array}{l}\text { The teacher should not merely rely on Learning Management System (LMS), an } \\
\text { effective learning can only happen if there is a real two-ways communication and } \\
\text { discussion between teacher and students. } \\
\text { Teachers should give feedback orally rather than written feedback because they think } \\
\text { that written feedback does not really help them to comprehend to achieve the } \\
\text { academic outcomes. }\end{array}$ \\
\hline
\end{tabular}

Table 2 shows that the three participants agreed that teachers played more important roles rather that the technologies used. They revealed that whatever the means of communication was, the more important thing was the two-way discussions. This finding is also supported by some other findings that state students view teachers having a significant and crucial role in online learning rather than merely technologies (Keller \& Cernerud, 2002; Rahmawati, 2016) since the teachers should provide continuous instruction and supervision to the students (Rahmawati, 2016). The fact that the participants of this study preferred oral feedback to written one is also supported by Rahmawati who argued that teachers should have continuous instruction and supervision, one of them is by having oral feedback (2016).

\section{CONCLUSION}

This paper examined the students' perspectives of teacher-students' interaction in an online learning environment. To collect the data, this study used interpretivist approach; interview to get the in-depth information from the participants. Moreover, the participants of this study are the higher education students who are pursuing their bachelor degrees in some private universities in Indonesia. All of them were asked about the effectiveness of teacherstudents interaction in an online learning environment and two students stated that online learning does not help them to communicate effectively with their teachers while one student 
said that discussion or communication in online learning can be happened effectively if students and teacher have teleconference meeting that can help them to communicate each other orally. Moreover, the three students were asked to give their own suggestion on how to make online learning effective to provide teacher-students interaction. The suggestions that were stated were; the teachers should not merely rely on LMS and have more two-ways discussion could be good and the feedbacks that are given should be delivered orally rather than written since it does not really help the students to understand the feedback, thus, it may supress their academic achievements.

\section{REFERENCES}

Arkorful, V., \& Abaidoo, N. (2015). The role of e-learning, advantages and disadvantages of its adoption in higher education. International Journal of Instructional Technology and Distance Learning, 12(1), 29-42.

Bakia, M., Shear, L., Toyama, Y., \& Lasseter, A. (2012). Understanding the implications of online learning for educational productivity. In Educational Technology. US Department of Education. http://ctl.sri.com/publications/displayPublication.jsp?ID=913

Bušelić, M. (2012). Distance learning - concepts and contributions. Oeconomica Jadertina, 1(2), 23-34. https://doi.org/10.15291/oec.209

Coldwell-Neilson, J., Craig, A., \& Goold, A. (2006). Student Perspectives of Online Learning. ALT-C 2006 Research Proceedings, 1, 97-107.

Creswell, J. W. (2014). Research design: Qualitative, quantitative, and mixed methods approaches (4th ed.). SAGE.

Elliott, V. F. (2018). Thinking about the coding process in qualitative data analysis. The Qualitative Report, 23(11), 2850-2861. https://ora.ox.ac.uk/objects/uuid:5304bf7f6214-4939-9f1b-b64415d4fac1

Fleming, J., \& Zegwaard, K. E. (2018). Methodologies, methods and ethical considerations for conducting research in work-integrated learning. International Journal of WorkIntegrated Learning, 19(3), 205-213.

Hartshorne, R., \& Ajjan, H. (2009). Examining student decisions to adopt Web 2.0 technologies: Theory and empirical tests. Journal of Computing in Higher Education, 21(3), 183-198. https://doi.org/10.1007/s12528-009-9023-6

Keller, C., \& Cernerud, L. (2002). Students' perceptions of e-learning in university education. Journal of Educational Media, 27(1-2), 55-67. https://doi.org/10.1080/1358165020270105

Kielmann, K., Cataldo, F., \& Seeley, J. (2012). Introduction to qualitative research methodology: A training manual, produced with the support of the department for international development (DfID). Evidence for Action Research Programme. www.write-arm.com

Ku, B. H., \& Lohr, L. L. (2000). A case study of Chinese students ' attitudes toward their first online learning experience. Internationa Review, 51(3), 95-102.

Lam, P., Lee, J., Chan, M., \& Mcnaught, C. (2011). Students ' use of e-learning strategies and their perceptions of e-learning usefulness (S.-M. Barton, J. Hedberg, \& K. Suzuki (eds.)). Proceedings of Global Learn Asia Pacific. http://www.editlib.org/p/37346.

Lara, S. (2006). Preparing teachers and schools for the 21 st century. Interactive Educational Multimedia, 12, 44-61.

Lefoe, G., Gunn, C., \& Hedberg, J. (2002). Recommendations for teaching in a distributed learning environment: The students' perspective. Australasian Journal of Educational Technology, 18(1), 40-56. https://doi.org/10.14742/ajet.1746

Little, D. (1995). Learning as dialogue: The dependence of learner autonomy on teacher autonomy. 23(2), 175-181. https://doi.org/10.1016/0346-251X(95)00006-6 
Malinovski, T., Lazarova, M., \& Trajkovik, V. (2012). Learner-content interaction in distance learning models: Students' experience while using learning management systems. International Journal of Innovation in Education, 1(4), 362. https://doi.org/10.1504/ijiie.2012.052737

Mason, J. (2002). Qualitative researching (2nd ed.). SAGE.

Najeeb, S. S. R. (2013). Learner Autonomy in Language Learning. Procedia - Social and Behavioral Sciences, 70, 1238-1242. https://doi.org/10.1016/j.sbspro.2013.01.183

Rahmawati, F. (2016). E-Learning implementation: Its opportunities and drawbacks perceived by EFL students. Journal of Foreign Languange Teaching and Learning, 1(1). https://doi.org/10.18196/ftl.111

Silverman, D. (2011). Qualitative Research (D. Silverman (ed.); 3rd ed.). SAGE Publication, Ltd.

Singh, G., Donoghue, J. O., \& Worton, H. (2002). A study into the effects of e-learning on higher education. Journal of University Teaching \& Learning Practice, 2(1), 1-24. https://doi.org/10.1136/jcp.2003.013581

Terzi, S., \& Çelik, A. (2005). Teacher-Student Interactions in Distance Learning. The Turkish Online Journal of Educational Technology (TOJET), 4(1), 1303-6521.

Vaismoradi, M., Jones, J., Turunen, H., \& Snelgrove, S. (2016). Theme development in qualitative content analysis and thematic analysis. Journal of Nursing Education and Practice, 6(5). https://doi.org/10.5430/jnep.v6n5p100

Vilma, Ž. (2018). Implementing Ethical Principles in Social Research: Challenges, Possibilities and Limitations. Vocational Training: Research And Realities, 29(1), 1943. https://doi.org/10.2478/vtrr-2018-0003 